Kurt, E. (2020). Okul öncesi öğretmenlerinin dil gelişimi ile ilgili kavram geliştirmeye yönelik görüşleri. Ana Dili Eğitimi Dergisi, 8(4), 1332-1342.

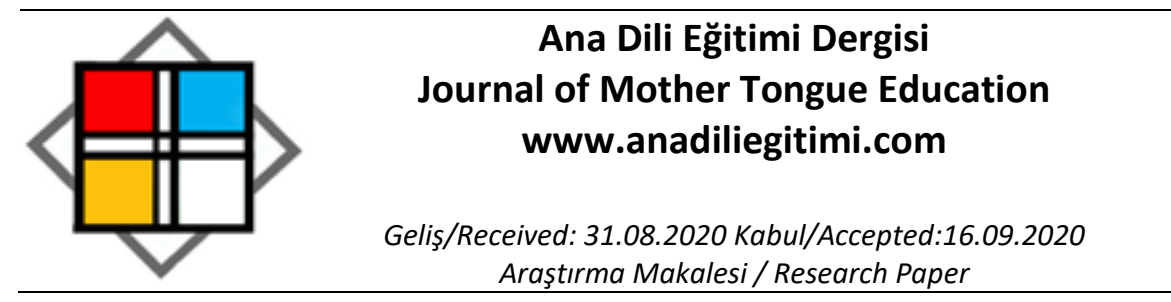

\title{
Okul Öncesi Öğretmenlerinin Dil Gelişimi ile İlgili Kavram Geliştirmeye Yönelik Görüşleri* $^{*}$
}

\author{
Elif Kurt
}

\begin{abstract}
Öz
Bu çalışma, okul öncesi öğretmenlerinin dil gelişimi ile ilgili kavram geliştirmeye yönelik görüşlerini tespit edip değerlendirmeyi amaçlamaktadır. Araştırma, bir örnek olay çalışmasıdır, 2019 yılında Millî Eğitim Bakanlığına bağlı okullarda görev yapmakta olan 6 okul öncesi öğretmeni ile sürdürülmüştür. Veriler, araştırmacı tarafından hazırlanan yarı yapılandırılmış görüşme formu aracılığı ile toplanmıştır. Veriler, sürekli karşılaştırmalı analiz metodu aracılı̆̆ı ile çözümlenmiştir. Araştırma sonunda ulaşılan sonuçlardan bazıları şunlardır: Okul öncesi öğretmenleri sınıfta kavram geliştirme çalışmaları sırasında kavramı somutlaştırmaya, kavramın ulaşılabilirliğine, öğrencinin hazır bulunuşluğuna, kavramla ilgili örnekler vermeye, dil kullanımına, kavramın benzerliklerini ve farklılıklarını vermeye dikkat etmektedir. Okul öncesi öğretmenlerinin sınıfta kavram geliştirme çalışmaları sırasında zorlandığı kavramlar zaman, boyut, duygu ile kavramlar ve renklerdir.
\end{abstract}

Anahtar Kelimeler: Okul öncesi, dil gelişimi, kavram.

\section{Pre-School Teachers' Views on Developing Concept Related to Language Development Abstract}

This study aimed to identify and evaluate the preschool teachers' views on developing concept related to language development. The research is a case study. The research was carried out in 2019 with 6 pre-school teachers working in schools affiliated to the Ministry of Education. The data from the study was collected through a semi-structured interview form prepared by the researcher. The data obtained as a result of interviews with the teachers were analyzed using the constant comparative analysis method. The research findings indicated that preschool teachers pay attention to embody the concept, accessibility of the concept, readiness of the student, giving examples related to the concept, use of language, giving similarities, and differences of the concept during the work on developing the concept in the classroom. Concepts that preschool teachers are forced to use during concept development work in the classroom are concepts with time, size, emotion, and colors.

Keywords: Pre-school, language development, concept

\section{Giriş}

Kavramlar, bireyin düşüncelerini sistematik hâle getiren ve iletişim sürecinin sağlıklı ilerlemesinde etkili olan olgulardır. Bir tür ile ilgili bulunan özelliklerin insan zihni tarafından birleştirilerek sonuç elde edilmesiyle oluşan yapı (Binbaşığlu, 1982) kavram olarak adlandırılmaktadır. Merrill (1983), kavramı aynı şekilde adlandırılan ve ortak özellikleri olan nesne topluluğu olarak tanımlar. Herhangi bir kavramın tanımı yapılırken o kavramın özelliklerinin ortaya çıkarılması gerekir. Kavramın en temel özellikleri "ayırt edici özellikler" ve "ayırt edici olmayan özellikler" adları altında sınıflandırılmaktadır. Ayırt edici özelliklerin yer aldığı herhangi bir öge, o kavrama ait olduğu için diğer ögelerden farklılaşmaktadır. Bundan dolayı kavramlar arası ilişkiler önemli hâle gelmektedir

\footnotetext{
*Dr., -, elifkurt07@hotmail.com, ORCID: 0000-0003-1040-0406
} 
(Martorella, 1986). Kavramın, nesne ile olguların ortak özelliklerinin bilişsel faaliyetlerle birleştirme ve tasnif etme ile etkileşimi bulunmaktadır.

Bireyler, hayatları boyunca kavramlar ile karşılaşır. Doğumdan sonra bireyler, kavram edinmeye başlar ve süreç içinde kavram öğrenme gelişir. Uyaranların birtakım gruplara ayrılarak zihinde bilgiler edinilmesi kavram öğrenme olarak tanımlanır. Kavram öğrenme, bir tür yapılanmayapılandırma işlemi olarak nitelendirilir (Ülgen, 2004). Kavram öğrenme sürecinde bireyler olay, olgu ve nesneleri inceleyerek zihinlerinde şemalar oluşturur. Bireyin yaşı arttıkça yaşantılarıyla doğru orantılı olarak dil gelişimi ile bağlantılı öğrendiği kavramlar da artar. Millî Eğitim Bakanlığı (2015), "Çocuk Gelişimi ve Eğitimi, 0-72 Ay Dil Gelişimi" modülünde, dilin kazanılmasının çocukta bilişsel gelişime dayandığını belirterek, zihinsel uyum ile ilgili süreçlerin algılama, dil kazanımı ve kavram gelişimi ile bağlantlı olduğunu ifade eder.

Çocuklar kavramlar ile ilgili yardıma intiyaç duyduğunda evde aileden ve yakın sosyal çevredeki kişilerden yararlanır. Okul ise kavram öğretiminin formal olarak başladığı yerdir. Bu noktada bilinçli, planlı kavram öğretimi ortaya çıkmaktadır.

Kavram öğretimi, bir kavramın ilişkili olan ya da olmayan özellikleriyle beraber aynı kavramın taksonomik seviyesini belirlemeyi buna ek olarak kavramın olumlu ve olumsuz olan özelliklerini aktarmayı gerektiren bir süreç (Vuran ve Çelik, 2008) olarak tanımlanır. Kavram öğretimi, kişinin zihninde kavramların oluşturulması ve tasnif edilmesine yardım etmeyi amaçlayan bir süreçtir.

Kavram öğretiminin, temel amacı çocukların bulundukları çevreyi tanımalarını ve anlamlandırmalarını sağlamaktır. Kavram öğretimi ile bilinçlenen çocuklar dili daha işlevsel ve etkili kullanacakları için iyi iletişim kuran bireyler hâline gelecektir. Bundan dolayı kavram öğretiminin bireylerin yakından uzağa doğru bilgi edinmekten toplumsallaşmaya kadar birçok açıdan işlevinin olduğu ifade edilebilir.

Çocuklar doğumdan sonra, aile ve yakın çevreden elde ettikleri tecrübelerle somut kavramları edinirler. Ancak soyut kavramların çoğunluğu, gelişim dönemleri kapsamında okul döneminde bulunduğu için öğretmenler aracııı̆ı ile öğrenilir. Bu açıdan bakıldığında çocukları okulda kavramlar ile tanıştıran ilk kişiler okul öncesi öğretmenleridir.

Okul öncesi öğretmenleri, çocuklarda temel kavramları geliştirme açısından çok önemli bir rol üstlenmektedir. Okul Öncesi Eğitim Programı'nda kavramlara kategoriler altında şu şekilde yer verilmiştir (Millî Eğitim Bakanlığı, 2013):

- Renk kategorisi

- "Geometrik Şekil" kategorisi: Daire, çember, üçgen, kare, dikdörtgen, elips, kenar, köşe kavramları.

- "Boyut” kategorisi: Büyük-orta-küçük, ince-kalın, uzun-kısa, geniş-dar kavramları.

- "Miktar" kategorisi: Az-çok, ağır-hafif, boş-dolu, tek-çift, yarım-tam, eşit, kalabalık-tenha, parça-bütün, para kavramları.

- "Yön/ Mekânda Konum" kategorisi: Ön-arka, sağ-sol, ileri-geri, önünde-arkasında, alt-üstorta, altında-ortasında-üstünde, yanında, yukarıda-aşağıda, iç-dış, içinde-dışında, içeri-dışarı, uzak-yakın, alçak-yüksek, sağında solunda kavramları.

- "Sayı/ Sayma" kategorisi: 1-20 arası sayılar, sıfır, ilk-orta-son, önceki-sonraki, sıra sayısı (birinci, ikinci...) kavramları.

- "Duyu" kategorisi: Tatlı, tuzlu, acı, ekşi, sıcak-soğuk-ılık, sert-yumuşak, kaygan-pütürlü, sivriküt, kokulu-kokusuz, parlak-mat, taze-bayat, sesli-sessiz kavramları.

- "Duygu" kategorisi: Mutlu, üzgün, kızgın, korkmuş, şaşkın kavramları.

- "Zıt" kategorisi: Aynı-farklı-benzer, açık-kapalı, hızı-yavaş, canlı-cansız, hareketli-hareketsiz, kolay-zor, karanlık-aydınlık, ters-düz, eski-yeni, başlangıç-bitiş, kirli-temiz, aç-tok, düz-eğri, güzel-çirkin, doğru-yanlış, şişman-zayıf, yaşlı-genç, derin-sığ, açık-koyu kavramları.

- "Zaman" kategorisi: Önce-şimdi-sonra, sabah-öğle-akşam, dün-bugün-yarın, gece- gündüz kavramları. 
Programda yer verilen bu kavramların kazandırılmasında etkin rol oynayan okul öncesi öğretmenlerinin kavram geliştirme ile ilgili yaptığı çalışmalar, çocukların dil gelişimi açısından büyük önem taşımaktadır.

Bu çalışmada, okul öncesi öğretmenlerinin dil gelişimi ile ilgili kavram geliştirmeye yönelik görüşlerini tespit edip değerlendirmek amaçlanmıştır.

\section{Araştırmanın Modeli}

\section{Yöntem}

Okul öncesi öğretmenlerinin dil gelişimi ile ilgili kavram geliştirmeye yönelik görüşlerini tespit edip değerlendirmeyi amaçlayan bu çalışmada nitel yaklaşım temel alınmıştır. Araştırma, bir örnek olay çalışmasıdır. Örnek olay çalışmasında yoğunlaşılan özel bir durum vardır. Bu durum bir olay, bir kişi ya da bir grup olabilir. Bu yöntem araştırmacılara çok özel bir konu veya durum ile ilgili yoğunlaşma fırsatı verir (Çepni, 2009).

\section{Araştırma Grubu}

Araştırma, 2019 yılının nisan ve mayıs aylarında Millî Eğitim Bakanlığına bağlı okullarda görev yapmakta olan 6 okul öncesi öğretmeni ile sürdürülmüştür. Araştırma grubunun seçiminde kolay ulaşılabilir durum örneklemesinden faydalanılmıştır. Öğretmenlerin çalışmaya katılımında gönüllük ilkesi esastır. Katıımcı öğretmenler; Ö1, Ö2, Ö3, Ö4, Ö5 ve Ö6 şeklinde kodlanmıştır.

Tablo 1.

Katılımcılara ait kişisel bilgiler

\begin{tabular}{|c|c|c|c|c|}
\hline 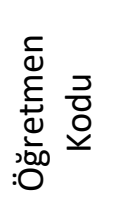 & Cinsiyet & $\begin{array}{l}\text { Hizmet } \\
\text { Süresi/Yıl }\end{array}$ & $\begin{array}{c}\text { Sınıfının Mevcudu/ } \\
\text { Öğrenci }\end{array}$ & $\begin{array}{c}\text { Sınıfının Yaş } \\
\text { Grubu }\end{array}$ \\
\hline Ö1 & Kadın & 13 & 20 & 3 \\
\hline Ö2 & Kadın & 4 & 20 & $5-6$ \\
\hline Ö3 & Kadın & 3 & 16 & $3-4$ \\
\hline Ö4 & Kadın & 3 & 12 & 5 \\
\hline Ö5 & Kadın & 3 & 22 & $4-5-6$ \\
\hline Ö6 & Kadın & 9 & 21 & $5-6$ \\
\hline
\end{tabular}

Tablo 1'de araştırmaya katılan öğretmenler ile ilgili ön bilgilere yer verilmiştir. Bu bilgilere göre, araştırma katılımcısı okul öncesi öğretmenlerinin tümü kadındır. Öğretmenlerin hizmet süresi 3 ile 13 yıl arasındadır. Öğretmenler 3-6 yaş grubunda değişen öğrenciye sahiptir. Son olarak katılımcı öğretmenlerin sınıf mevcutları 16 ile 22 arasındadır.

\section{Veri Toplama Araçları}

Çalışmaya ait veriler, araştırmacı tarafından hazırlanan yarı yapılandırılmıs görüşme formu aracılığı ile toplanmıştır.

Görüşme formu, 2 bölüm ile 11 maddeden oluşmaktadır. Birinci bölüm, katılımcılar ile ilgili bireysel bilgilere ulaşmayı amaçlayan 4 maddeden oluşmaktadır. İkinci bölümde ise okul öncesi öğretmenlerinin dil gelişimi kapsamında kavram geliştirme çalışmalarını belirlemeye yönelik 7 madde bulunmaktadır.

\section{Verilerin Toplanması}

Çalışma verileri 2019 yılının nisan ve mayıs aylarında Millî Eğitim Bakanlığına bağlı okullarda görev yapmakta olan 6 okul öncesi öğretmeni ile yapılan görüşmeler aracılığı ile toplanmıştır. Okul öncesi öğretmenleri ile birebir görüşmeler yapılarak onların dil gelişimi kapsamındaki kavram 
geliştirme çalışmalarının çeşitliliği belirlenmiştir. Bu süreçte elde edilen veriler kodlanarak kategorilere ayrılmıştır.

\section{Verilerin Analizi}

Öğretmenlerle yapılan görüşmeler sonucunda elde edilen veriler, sürekli karşılaştırmalı analiz metodu aracılı̆ı̆ ile çözümlenmiştir. Ekiz, (2009)'e göre sürekli karşılaştırmalı analiz, eldeki verilerin tümevarımsal şekilde kodlanarak eldeki diğer verilerle sürekli karşılaştırılmasıdır. Araştırma kapsamında analiz edilmiş olan veriler, tablolar ile gösterilmiştir. Tablolar, araştırmaya katılan öğretmenlerin görüşlerinden alıntılar yapılarak açıklanmıştır.

\section{Geçerlik ve Güvenirlik}

Görüşme formu ile ilgili 5 alan uzmanından görüş alınmıştır. Görüşler sonrası form üzerinde gerekli düzenlemeler yapılmışır. Bunun yanında görüşme formu, verilerin toplanmasından önce 3 öğretmen ile pilot uygulama yapılarak anlaşılırlık ve açıklık açısından sınanmıştır.

Araştırmanın güvenirliği için veriler ikinci bir alan uzman tarafından analiz edilmiştir. Güvenirliğin hesaplanması Kappa İstatistiği kullanılarak yapılmıştır. Kan (2013)'a göre, iki puanlayıcının puanlama yapılması durumunda güvenirliğe ait katsayının ortaya çıkarılması için Kappa İstatistiği kullanılabilir. Araştırmamızdan elde edilen veriler doğrultusunda Kappa katsayısı 0.71 olarak bulunmuştur. Türkiye İstatistik Kurumu (2011), Kappa katsayısının 0,61 ile 0,80 arasında olduğu durumlarda puanlayıcılar arasında önemli bir uzlaşma olduğunu ifade eder. Bu doğrultuda araştırma verilerinin güvenilir olduğu söylenebilir.

\section{Bulgular}

Bu bölümde, okul öncesi öğretmenleri ile yapılan yarı yapılandırılmış görüşmeler sonucu elde edilen bulgular sunulmuştur.

Araştırmaya katılan öğretmenlerin öğretmenlerinin sınıfta kavram geliştirme çalışmalarına yer verme sıklığı ve bu çalışmalarının gerekliliği ile ilgili görüşleri Tablo 2'de sunulmuştur.

Tablo 2.

Okul öncesi öğretmenlerinin sınıfta kavram geliştirme çalışmalarına yer verme sıklığı

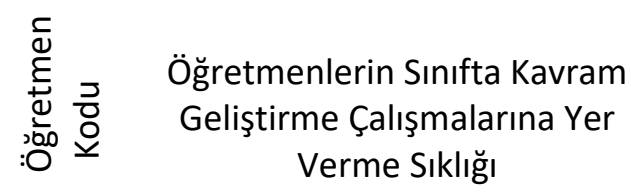

\begin{tabular}{ll}
\hline Ö1 & Haftada 3 kez \\
Ö2 & Haftanın her günü \\
Ö3 & Haftada 2 kez \\
Ö4 & Haftanın her günü \\
Ö5 & Haftada 3 kez \\
Ö6 & Haftanın her günü \\
\hline
\end{tabular}

Tablo 2'de, katılımcı öğretmenlerin sınıfta kavram geliştirme çalışmalarına haftanın her günü ile haftada 2 kez arası bir sıklıkta yer verdiği görülmektedir. Sınıfında kavram geliştirme çalışmalarını her gün yaptıran 3, haftada 3 kez yaptıran 2 ve haftada 2 kez yaptıran 1 katılımcı öğretmen bulunmaktadır. 
Tablo 3.

Okul öncesi öğretmenlerinin sınıfta kavram geliştirme çalışmaları sırasında zorlandığı kavramlar ve ögretmenlerin sınıfta kavramları tekrar etme durumları

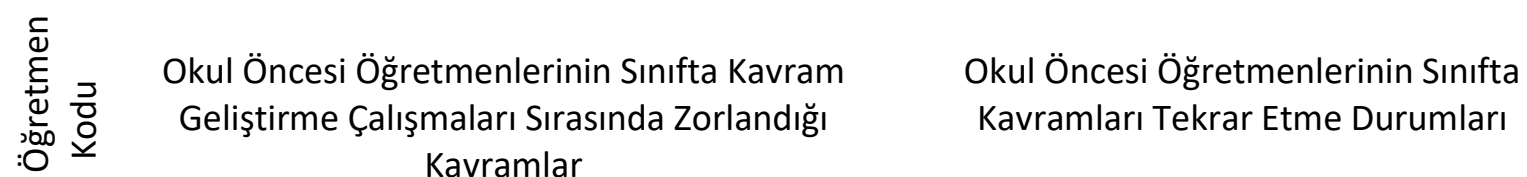

\begin{tabular}{lllll}
\hline Ö1 & - & Renkler & - & Boyama etkinlikleri sırasında \\
& - & Boyut ile ilgili kavramlar & - & Oyun oynarken \\
Ö2 & - & Zaman ile ilgili kavramlar & - & Oyun oynarken \\
Ö3 & - & Duygu ile ilgili kavramlar & - & Oyun oynarken \\
Ö4 & - & Zaman ile ilgili kavramlar & - & Sınıf içi konuşmalarda \\
Ö5 & - & Zaman ile ilgili kavramlar & - & Sınıf içi konuşmalarda \\
& & & & \\
Ö6 & - & Zaman ile ilgili kavramlar & - & Boyama etkinlikleri sırasında \\
\hline
\end{tabular}

Tablo 3'e göre okul öncesi öğretmenlerinin sınıfta kavram geliştirme çalışmaları sırasında zorlandığı kavramlar şunlardır:

- Zaman ile ilgili kavramlar

- Boyut ile ilgili kavramlar

- Duygu ile ilgili kavramlar

- Renkler

Katılımcı okul öncesi öğretmenlerinin sınıfta kavram geliştirme çalışmaları sırasında en çok zorlandığı kavramlar zaman ile ilgili olanlardır.

Araştırmaya katılan öğretmenlerden Ö2: Dün-bugün-yarın, gece-gündüz gibi kavramlarda zorlanıyorum. Ifadeleriyle zaman kavramlarında zorlandığını belirtmiştir. Ö1 ise duygu ile ilgili kavramlara dikkat çekerek görüşlerini şu şekilde ifade etmiştir: Ö1: Büyük-küçük, uzun-kısa kavramları zor oluyor. 'Aynı yaştasınız.' diyorum. 'Ama o benden büyük, çünkü boyu büyük.' diyor.

Tablo 3’e bakıldığında okul öncesi öğretmenlerinin tamamının sınıfta kavramları tekrar ettiği görülür. Öğretmenler kavramları şu şekillerde tekrar etmektedir:

- Oyun oynarken

- Sınıf içi konuşmalarda

- Boyama etkinlikleri sırasında

Katılımcı öğretmenler, sınıf içinde kavramları en fazla sınıf içi konuşmalarda ve boyama etkinlikleri sırasında tekrar etmektedir.

Oyun oynarken kavramları tekrar ettiğini söyleyen Ö2, görüşlerini şu şekilde dile getirmiştir: Ö2: Oyun oynarken kavramları özellikle tekrar ediyorum. Mesela: "Bana şu küçük yapbozu uzatır mısın?" diyorum, vurguluyorum. Sınıf içi konuşmalarda kavramları tekrar ettiğini belirten Ö8: Mesela sınıf içinde bir şey yaşadık, ya da söz arasında o nesne geçti, hemen tekrar ediyorum. Şeklinde görüş bildirmiştir. 
Tablo 4.

Öğretmenlerin sınıfta kavram geliştirme çalışmaları ile ilgili yaptırdığı etkinlik türü ve bu etkinlikleri oluşturma şekilleri

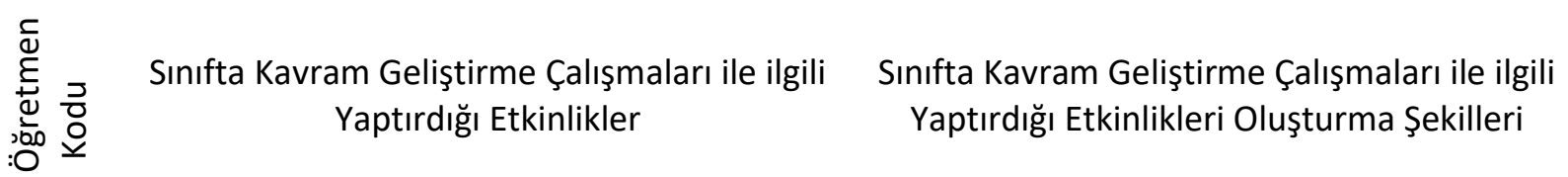

\begin{tabular}{lllll}
\hline Ö1 & - & Oyun-hareket etkinlikleri & - & Internetten bakarak \\
Ö2 & - & Oyun-hareket etkinlikleri & - & Internetten bakarak \\
& - & Deney etkinliği & - & Üniversite notlarından yararlanarak \\
& - & Kâğıt etkinlikleri & & \\
Ö3 & - & Boyama etkinliği & - & Internetten bakarak \\
& & & - & Dergilerden yararlanarak \\
Ö4 & - & Sanat etkinlikleri & - & Kendisi üreterek \\
& - & Kâğıt etkinlikleri & & \\
Ö5 & - & Oyun-hareket etkinlikleri & - & Internetten bakarak \\
& - & Sanat etkinlikleri & - & Üniversite notlarından yararlanarak \\
Ö6 & - & Kâğıt etkinlikleri & - & Internetten bakarak \\
& & & - & Kendisi üreterek \\
\hline
\end{tabular}

Tablo 4'te öğretmenlerin sınıfta kavram geliştirme ile yaptırdığı etkinliklere yer verilmiştir. Katılımcı öğretmenlerin sınıfta kavram geliştirme ile yaptırdığı etkinlikler şunlardır:

- Oyun-hareket etkinlikleri

- Deney etkinliği

- Kâğıt etkinlikleri

- Sanat etkinlikleri

- Boyama etkinliği

Araştırmaya katılan okul öncesi öğretmenleri sınıfta kavram geliştirme ile ilgili en fazla oyunhareket ve kâğıt etkinliklerini yaptırmaktadır.

Sınıfta kavram geliştirme ile ilgili sanat ve kâğıt etkinlikleri yapan ö4: Bazı kavramları sanat etkinlikleriyle veriyorum. ilgi çekici ve kalıcı oluyor. Bazen da kâğıt etkinlikleri yapıyorum. Sanat ve oyunhareket ekinlikleri yapan Ö5 ise kendisini şu şekilde ifade etmiştir: Ö5: Genellikle somut kavramlar ağırıkta olduğu için ya oyun-hareket ya da sanat etkinliklerine yer veriyorum.

Araştırmaya katılan okul öncesi öğretmenleri sınıfta kavram geliştirme ile ilgili yaptıkları etkinlikleri şu yollarla oluşturmaktadır:

- Internetten bakarak

- Üniversite notlarından yararlanarak

- Dergilerden yararlanarak

- Kendisi üreterek

Sınıfta kavram geliştirme ile ilgili yaptıkları etkinlikleri internetten bakarak oluşturan öğretmen sayısı çoğunluktadır.

Kavram geliştirmede kullandığı etkinlikleri kendisi üreten Ö4'ün bu konudaki görüşleri şu şekildedir: Ö4: Önceki tecrübelerimden hareket ederek, "Aaa, bunu böyle verebilirim." diyorum. Aklıma böyle geliyor etkinlikler, kendim üretiyorum. Kavram etkinliklerini internetten bulan ya da kendisi üreten Ö6 ise görüşlerini şu şekilde ifade etmiştir: Ö8: Etkinliklerimi kendim oluşturuyorum, sürekli yaptığım etkinlikler var. Bazen de internetten bakıyorum nasıl çeşitlendirebilirim diye. 
Tablo 5.

Okul öncesi öğretmenlerinin sınıfta kavram geliştirme çalışmaları sırasında dikkat ettiği noktalar

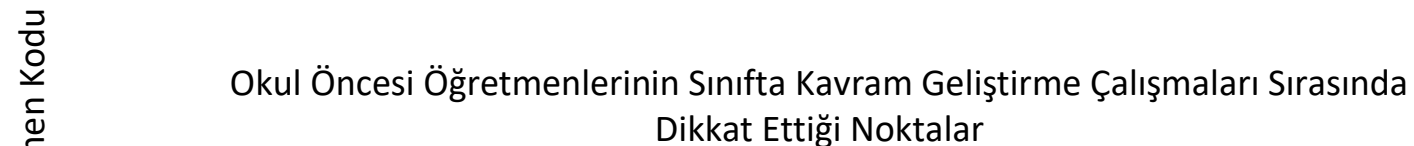

Dikkat Ettiği Noktalar

\begin{tabular}{lll}
\hline Ö1 & - & Kavramı somutlaştırma \\
& - & Kavramın ulaşılabilirliğine dikkat etme \\
Ö2 & - & Öğrencinin hazır bulunuşluğuna dikkat etme \\
& - & Kavramı somutlaştırma \\
Ö3 & - & Kavramı somutlaştırma \\
& - & Kavramla ilgili örnekler verme \\
Ö4 & - & Dil kullanımına dikkat etme \\
Ö5 & - & Kavramın benzerliklerini ve farklııklarını verme \\
& - & Kavramla ilgili örnekler verme \\
Ö6 & - & Kavramı somutlaştırma \\
\hline
\end{tabular}

Tablo 5'e göre okul öncesi öğretmenlerinin sınıfta kavram geliştirme çalışmaları sırasında dikkat ettiği noktalar şunlardır:

- Kavramı somutlaştırma

- Kavramın ulaşılabilirliğine dikkat etme

- Öğrencinin hazır bulunuşluğuna dikkat etme

- Kavramla ilgili örnekler verme

- Dil kullanımına dikkat etme

- Kavramın benzerliklerini ve farklılıklarını verme

Okul öncesi öğretmenleri sınıfta kavram geliştirme çalışmaları sırasında en fazla kavramı somutlaştırmaya dikkat etmektedir.

Katılımcı öğretmenlerden Ö3:Kavramları anlatırken açık ve anlaşılır ifadeler kullanıyorum. Kullanacağım kelimeleri kuracağım cümleleri titizlikle seçiyorum. Ifadeleriyle kavram geliştirme sırasında dil kullanımına dikkat ettiğini belirtmiştir. Ö5 ise kavramın benzerliklerini ve farklııklarını vererek kavramı örneklendirdiğini şu şekilde ifade etmiştir: Ö5: Kavramlar genelde zıttıyla birlikte oluyor. Sıcak-soğuk gibi. O yüzden ayrımlarını veriyorum. Sıcak nasıl sıcak, soğuk nasıl soğuk ayrımını kavratmaya dikkat ediyorum. Bunlarla ilgili örnekleri çoğaltıyorum.

Tablo 6.

Okul öncesi öğretmenlerinin sınıftaki kavram geliştirme çalışmalarında kullandığı materyaller

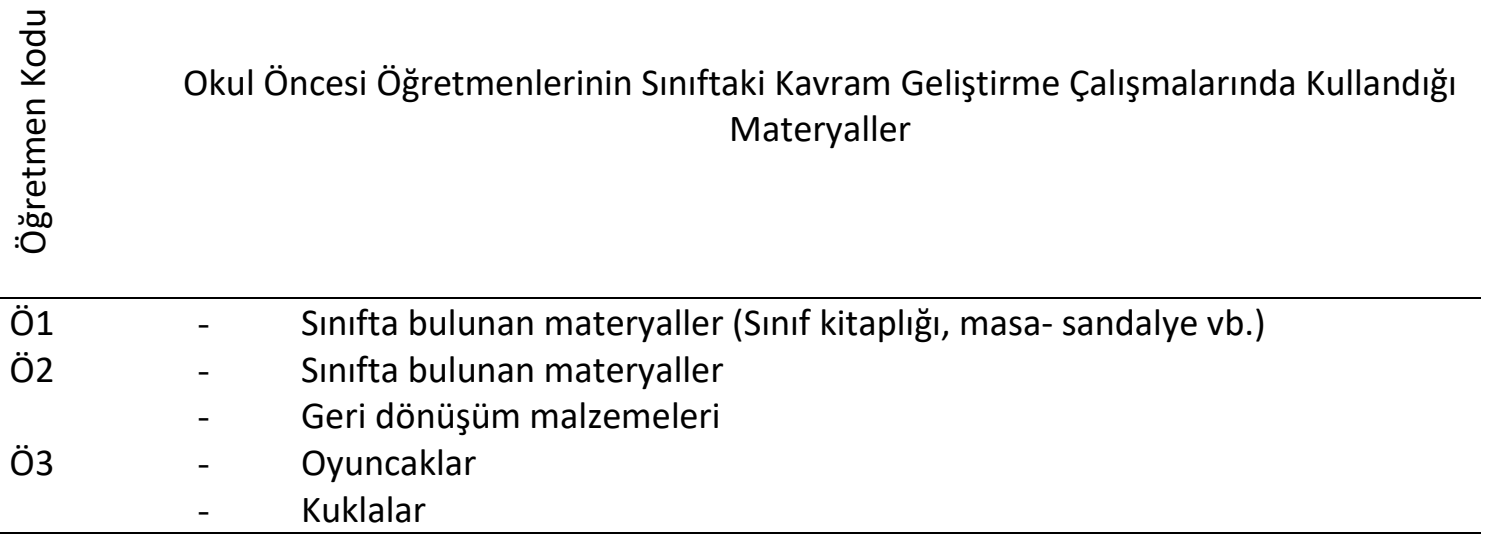




\begin{tabular}{lll}
\hline Ö4 & - & Hikâye kartları \\
& - & Sinıfta bulunan materyaller \\
& - & Kendi yaptığı materyaller \\
Ö5 & - & Yiyecekler \\
Ö6 & - & Sinıfta bulunan materyaller \\
\hline
\end{tabular}

Tablo 6'da görülen okul öncesi öğretmenlerinin sınıftaki kavram geliştirme çalışmalarında kullandığı materyaller şu şekilde sıralanabilir:

- Sinifta bulunan materyaller

- Kavramla ilgili örnekler verme

- Oyuncaklar

- Kuklalar

- Hikâye kartları

- Öğretmenin kendi yaptığı materyaller

- Yiyecekler

Okul öncesi öğretmenleri sınıftaki kavram geliştirme çalışmalarında en fazla sınıfta bulunan mevcut materyallerden yararlanmaktadır.

Araştırmaya katılan öğretmenlerden Ö2 kavram öğretirken sınıfta bulunan materyalleri ve geri dönüşüm malzemelerini kullandığını şöyle ifade etmiştir: Ö2: Eğer sınıfımda uygun materyal varsa onları kullanıyorum. Sınıftaki oyuncak teraziyle ağır-hafifi öğrettim. Geri dönüşüm materyallerini de değerlendiriyorum. Yine ağır-hafif için eski bir askı ile çöp toplattım. Ö4 kavramları verirken sınıfta bulunan ve kendi yaptığı materyallere ek olarak yiyecekleri kullandığını şu şekilde ifade etmiştir: Ö4: Kavrama göre kullandığım materyal değişiyor. Mesela bir küp hazırlıyorum. Küpün üstüne sayıları yazıyorum. Renklerine göre şekiller yapıştırıyorum. Kırmızı daireyi ya da sayıları bulduruyorum. Sivri-küt kavramını vereceğim diyelim. Sınıftaki bütün materyalleri kullanıyorum. Acı-tatı kavramında yiyecekler getiriyorum.

Tablo 7.

Okul öncesi öğretmenlerinin kavram gelişimini ölçmede izlediği yollar

Okul Öncesi Öğretmenlerinin Kavram

Gelişimini Ölçmede İzlediği Yollar Öğretmenlerinin Kodu

\begin{tabular}{ll}
\hline Soru-cevap & Ö1, Ö3, Ö4, \\
Ev ödevi & Ö2 \\
Aile görüşmeleri & Ö2 \\
Yarışmalı oyunlar & Ö5 \\
Etkinlikler & Ö5 \\
\hline
\end{tabular}

Tablo 7'de okul öncesi öğretmenlerinin kavram gelişimini ölçmede izlediği yollar sunulmuştur. izlemektedir:

Araştırmaya katılan okul öncesi öğretmenleri kavram gelişimini ölçmede şu yolları

- Soru-cevap

- Ev ödevi verme

- Aile görüşmeleri yapma

- Yarışmalı oyunlar oynatma

- Etkinlikler 


\section{Katılımcı öğretmenler kavram gelişimini ölçmede en fazla soru-cevap yöntemini kullanmaktadır.}

Araştırmaya katılan öğretmenlerden Ö4: Ilerleyen günlerde: 'Aaa bu neydi?' diyorum. Mesela bir oyuncak kırıldı diyelim. Neden atmamamı gerekiyor, diye soruyorum. Sivri cevabını alıyorum. şeklinde görüş bildirerek soru-cevap yöntemini kullandığını belirtmiştir. Yine soru-cevap yöntemini vurgulayan Ö6: Ara ara soruyorum. Bu ne renk, uzun mu kısa mı diye. Sözleriyle kendini ifade etmiştir.

\section{Tartışma ve Sonuç}

Araştırma sonunda şu sonuçlara ulaşılmıştır:

Katılımcı okul öncesi öğretmenlerinin sınıfta kavram geliştirme çalışmalarına haftanın her günü ile haftada 2 kez arası bir sıklıkta yer verdiği görülmüştür. Akman (1995), çocukların kavram gelişimlerinde kavram eğitiminin etkisini incelediği çalışmasında nitelikli eğitim ve kavram kazanma becerisi arasında olumlu bir ilişkinin bulunduğu sonucuna ulaşmıştır.

Okul öncesi öğretmenlerinin sınıfta kavram geliştirme çalışmaları sırasında zorlandığı kavramlar zaman, boyut, duygu ile kavramlar ve renklerdir. Katılımcı okul öncesi öğretmenlerinin sınıfta kavram geliştirme çalışmaları sırasında en çok zorlandığı kavramlar zaman ile ilgili olanlardır.

Okul öncesi öğretmenlerinin tamamının sınıfta kavramları tekrar ettiği görülür. Öğretmenler kavramları oyun oynarken, sınıf içi konuşmalarda ve boyama etkinlikleri sırasında tekrar etmektedir. Millî Eğitim Bakanlığı Okul Öncesi Eğitim Programı (2013) da kavramların değişik etkinliklerde tekrar ele alınabileceğini belirtmektedir.

Katılımcı öğretmenler sınıfta kavram geliştirme ile ilgili oyun- hareket, deney, kâğıt, sanat ve boyama etkinlikleri yaptırmaktadır. Araştırmaya katılan okul öncesi öğretmenlerinin sınıfta kavram geliştirme ile ilgili en fazla oyun- hareket ve kâğıt etkinliklerini yaptırdığı sonucuna ulaşılmıştır. Sınıftaki oyun-hareket ekinlikleriyle kavram gelişimini sağlayan öğretmenlerin görüşlerine paralel olarak Çağlak (1999) çalışmasında, beden eğitimi etkinlikleri ile desteklenmiş bir programın okul öncesi 5-6 yaş grubu çocukların enerji kavramı gelişiminde geleneksel eğitime kıyasla daha etkili olduğu sonucuna ulaşmıştır. Yine araştırmaya katılan ve kavram geliştirmede sanat ve oyun etkinlikleri yapan öğretmenlerin görüşlerine paralel olarak Sevinç ve Kurtuluş (2004), 5-6 yaş çocukları ile yaptıkları bir çalışmada, kavramlarda, sanat ve oyuna dayalı etkinlikleri içeren eğitim programlarının etkili olduğu sonucuna ulaşmışlardır.

Araştırmaya katılan okul öncesi öğretmenleri sınıfta kavram geliştirme ile ilgili yaptıkları etkinlikleri internetten bakarak, üniversite notlarından ve dergilerden yararlanarak ya da kendisi üreterek oluşturmaktadır. Sınıfta kavram geliştirme ile ilgili yaptıkları etkinlikleri internetten bakarak oluşturan katılımcı sayısı çoğunluktadır.

Okul öncesi öğretmenleri sınıfta kavram geliştirme çalışmaları sırasında kavramı somutlaştırmaya, kavramın ulaşılabilirliğine, öğrencinin hazır bulunuşluğuna, kavramla ilgili örnekler vermeye, dil kullanımına, kavramın benzerliklerini ve farklııklarını vermeye dikkat etmektedir. Okul öncesi öğretmenleri sınıfta kavram geliştirme çalışmaları sırasında en fazla kavramı somutlaştırmaya dikkat etmektedir.

Okul öncesi öğretmenleri sınıftaki kavram geliştirme çalışmalarında sınıfta bulunan eşyaları, oyuncakları, kuklaları, hikâye kartlarını, yiyecekleri ve kendi yaptıkları materyalleri kullanmaktadır. Okul öncesi öğretmenleri sınıftaki kavram geliştirme çalışmalarında en fazla sınıfta bulunan mevcut materyallerden yararlanmaktadır. Çelik (2005), okul öncesinde bulunan 6 yaş çocuklarının zaman kavramını algılaması ile ilgili yapmış olduğu çalışmasında, okul öncesi eğitiminde eğitici oyuncakların zaman kavramının verilmesinde etkili olduğu sonucuna ulaşmıştır.

Araştırmaya katılan okul öncesi öğretmenlerinin kavram gelişimini ölçmede soru-cevap, ev ödevi verme, aile görüşmeleri yapma, yarışmalı oyunlar oynatma ve etkinlik düzenleme gibi yollara başvurmaktadır. Katılımcı öğretmenler kavram gelişimini ölçmede en fazla soru-cevap yöntemini kullanmaktadır. 


\section{Kaynaklar}

Akman, B. (1995). Anaokuluna devam eden 40-69 aylık çocukların kavram gelişimlerinde kavram eğitiminin etkisinin incelenmesi. Ankara: Hacettepe Üniversitesi, Yayımlanmamış Doktora Tezi. Binbaşıŏlu, C. (1982). Gelişim psikolojisi. Ankara: Binbaşığlu Yayınevi.

Çağlak, S. (1999). Okul öncesi eğitim kurumlarına devam eden 5-6 yaş çocuklarına beden eğitimi etkinlikleri yoluyla kavram (enerji) öğretimi. İstanbul: Marmara Üniversitesi Yayımlanmamış Yüksek Lisans Tezi.

Çelik, C. (2005). Oyun materyallerinin okul öncesi eğitim çağındaki çocukların kavram gelişimi üzerindeki etkisinin incelenmesi. Konya: Selçuk Üniversitesi, Yayımlanmamış Doktora Tezi.

Çepni, S. (2009). Araştırma ve proje çalışmalarına giriş. Celepler Matbaacılık: Trabzon.

Ekiz, D. (2009). Bilimsel araştırma yöntemleri, yaklaşım, yöntem ve teknikler. Ankara: Anı Yayıncılık.

Kan, A. (2013). Ölçme araçlarında bulunması gereken nitelikler. H. Atılgan (Ed.), Eğitimde ölçme ve değerlendirme (ss. 23-80). Ankara: Anı Yayıncılık.

Martorella, P. H. (1986). Teaching concepts. classroom teaching skills. USA: Healty and Company.

Merrill, M. D. (1983). Component display theory, Instructional desing theories and models. In C. M. Reigeluth (Eds.), An overwiew of their current status (pp. 279-333). Hillsdale, NJ: Lawrence Erlbaum Associates.

Millî Eğitim Bakanlığı, (2013). Okul Öncesi Eğitim Programı. Ankara.

Millî Eğitim Bakanlığı, (2015). Çocuk Gelişimi ve Eğitimi, 0-72 Ay Dil Gelişimi. Ankara.

Sevinç, M. ve Kurtuluş, E. (2004). 5-6 Yaş Çocuklarında Çoklu Zekâ Kuramı Çerçevesinde Zaman Kavramının Kazanımı. HAYEF Journal of Education, 1(2), 25-41.

Türkiye İstatistik Kurumu. (2011). Istatistiksel Kalite Kontrol Sorularla Resmî Istatistikler Dizisi 11. Ankara: Türkiye İstatistik Kurumu Matbaası.

Ülgen, G. (2004). Kavram geliştirme, kuramlar ve uygulamalar. Ankara: Nobel.

Vuran, S. \& Çelik, S. (2008). Örneklerle kavram öğretimi. Ankara: Kök.

\section{Extended Abstract}

\section{Introduction}

A structure formed by combining the features found related to a species with the human mind to achieve a result (Binbaşıoğlu, 1982) is called a concept. Merrill (1983) defines the concept as a collection of objects that are similarly named and have common properties. There is an interaction of the common features of the concept, objects, and phenomena with combining and sorting with cognitive activities.

Individuals encounter concepts throughout their lives. After birth, individuals begin to acquire concepts, and concept learning develops in the process. Acquiring information in the mind by dividing stimuli into a number of groups is defined as concept learning. Concept learning is characterized as a kind of structuring-structuring process (Ülgen, 2004). In the process of learning concepts, individuals create schemas in their minds by studying events, facts and objects. As a person's age increases, the concepts that they learn in direct proportion to their lives also increase. A person does this sometimes by himself, sometimes by asking for help from others.

When children need help with concepts, they benefit from family at home and people in the immediate social environment. The school is where concept teaching begins formally. At this point, concept teaching is emerging.

Concept teaching is defined as a process that requires determining the taxonomic level of the same concept along with the associated or non-related properties of a concept, as well as transferring the positive and negative properties of the concept (Vural and Çelik, 2008). In short, concept teaching is a process that aims to help create and classify concepts in one's mind.

The main goal of concept teaching is to enable children to recognize and make sense of the environment in which they are located. Children who are conscious of concept teaching will become individuals who communicate well, as they will use language more functionally and effectively. Because of this, it can be expressed that concept teaching functions in many aspects, from the acquisition of closer information to socialization of individuals. 
After birth, children acquire concrete concepts through their experience in the family and the immediate environment. But the majority of abstract concepts are learned through teachers during the school period within the scope of development periods. From this point of view, preschool teachers are the first to introduce children to concepts in school.

Preschool teachers play a very important role in developing basic concepts in children. In the preschool education program of the Ministry of Education (2013), some concepts determined under the categories are included. The work of preschool teachers, who play an active role in acquiring the concepts contained in the program, on concept development is of great importance in terms of the language development of children.

\section{Method}

This study aimed to identify and evaluate the preschool teachers' views on developing concept related to language development. The research is a case study.

The research was carried out in 2019 with 6 pre-school teachers working in schools affiliated to the Ministry of Education.

Data from the study was collected through a semi-structured interview form prepared by the researcher. The validity and reliability of the interview form has been ensured. The interview form consists of 2 sections and 11 terms.

The data obtained as a result of interviews with teachers were analyzed using the constant comparative analysis method. The data analyzed within the scope of the research is shown by tables. The tables are explained by quoting the opinions of the teachers involved in the research.

\section{Result and Discussion}

It was observed that participating preschool teachers participated in concept development work in the classroom with a frequency from every day of the week to 2 times a week.

Concepts that preschool teachers are forced to use during concept development work in the classroom are concepts with time, size, emotion, and colors. The most difficult concepts that participating preschool teachers are forced to use during concept development work in the classroom are those related to time.

All pre-school teachers are seen repeating concepts in the classroom. Teachers repeat concepts while playing games, in-class conversations, and during painting activities.

Participating teachers conduct game - motion experiment activities, paper, art and painting activities that teachers do with concept development in the classroom. It was concluded that pre school teachers who participated in the study had the most play-movement and paper activities related to concept development in the classroom.

Pre-school teachers participating in the research constitute their activities related to concept development in the classroom by looking at the internet, using university notes and journals or producing them themselves. The number of participants who make up their activities related to concept development in the classroom by looking at the internet is the majority.

Preschool teachers pay attention to embody the concept, accessibility of the concept, readiness of the student, giving examples related to the concept, use of language, giving similarities and differences of the concept during the work on developing the concept in the classroom. Preschool teachers pay the most attention to embodying the concept during the development of concepts in the classroom.

Preschool teachers use items, toys, puppets, story cards, food and materials that they make in the classroom in their concept development work in the classroom. Preschool teachers use the most available materials available in the classroom in concept development work in the classroom.

In measuring the concept development of preschool teachers participating in the research, it applies to ways such as question-answer, homework, conducting family interviews, playing competitive games and organizing events. Participating teachers use the most question-and-answer methods to measure concept development. 